\title{
ENVIRONMENTAL IMPLICATION OF MSWI BOTTOM ASH UTILISATION
}

\section{Characteristics and Leaching Behaviour}

Peter E. Holm \& Ole Hjelmar

$V K I$

Denmark

\section{INTRODUCTION}

The development of environmentally sustainable utilisation and disposal strategies for combustion residues such as solid waste products from municipal solid waste incinerators (MSWIs) and coal fired power plants should be based on the best available knowledge of the short and long term leaching characteristics of the residues. The environmental impact may then be evaluated combining the knowledge about the leaching characteristics with information on the mobility and ecological properties of the released contaminants. To a large extent, this knowledge may be obtained through the performance of laboratory leaching experiments that in each case should be adapted to the relevant conditions. The laboratory results may in tum be used as input to a mathematical risk assessment model predicting the emission, transport and fate of the contaminants over a longer period of time. Most laboratory tests are accelerated and cannot take the effects of mineral ageing and weathering processes into account. Therefore, there is a definite need to verify and improve both the techniques and methods employed in laboratory leaching and attenuation studies and the methods of interpretation and modelling by comparing the results to actual field observations.

While the amount of previously reported and ongoing research on laboratory testing, particularly of the leaching properties of waste materials but also on the mobility of leached contaminants, is substantial, less information is available on the behaviour of actually land filled or utilised combustion residues. This is un- 
derstandable in the view of the difficulties involved in getting reliable field data that are representative of well-defined conditions.

This paper presents characteristics and leaching behaviour of MSWI residues in general and specifically in relation to utilisation of MSWI bottom ash as a subbase material at a parking lot.

\section{CHARACTERISTICS OF MSWI RESIDUES}

The various types of residues produced by modern MSW mass burn incinerators are bottom ash, grate siftings, boiler ash, economiser ash, fly ash and acid gas scrubbing residues. The specific amounts produced of the different types of MSWI residues may vary and reflect differences in waste composition, technological standards and operation parameters. Figure 1 shows mean data of solid mass stream in MSW incinerators. The data are from modern incinerators and compiled by IAWG (1997).

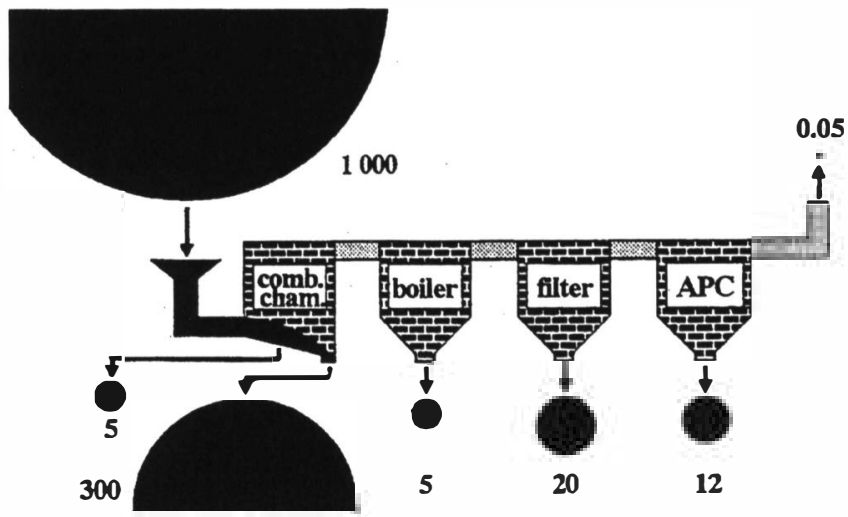

Fig: 1. Typical quantities of MSWI residues produced per tonne solid waste. From IAWG (1997).

The grate siftings and the boiler ash are often directly combined with the bottom ash, and economiser ash is nearly always combined with the fly ash that may be collected separately or as part of the acid gas scrubbing residues. In this paper the term "fly ash" is used exclusively for the fine particles which are carried over from the combustor with the flue gases and subsequently captured in electrostatic precipitators or fabric filters; it does not) include acid gas scrubbing residues. As seen in Figure 1, the bottom ash is the main waste stream (in average $300 \mathrm{~kg} /$ tonne waste) from the incineration process. The bottom (or grate) ash appears after quenching/cooling with water as a coarse, extremely inhomogeneous 
granulate, usually containing larger, fused lumps of slag and pieces of scrap metal. The grate siftings may also be relatively coarse whereas the other residues are much finer powders or (from the wet scrubbing process) a wastewater treatment sludge.

Table 1 shows the ranges of composition of MSWI bottom ash (excluding the scrap metal portion and the size fraction larger than $45 \mathrm{~mm}$ which typically constitutes 10 to $20 \%$ of the total weight), fly ash and acid gas scrubbing residues from the dry and semidry processes. 
Table 1. Ranges of composition of MSWI bottom ash and other residues. From Hjelmar (1996)

\begin{tabular}{|c|c|c|c|c|c|}
\hline Parameter & Unit & Bottom ash & Fly ash & $\begin{array}{l}\text { Acid gas scrubbing } \\
\text { residues from the } \\
\text { dry/semidry proc- } \\
\text { ess (incl. fly ash) }\end{array}$ & $\begin{array}{l}\text { Acid gas scrubbing } \\
\text { residues from the } \\
\text { wet process (sludge } \\
\text { mixed with fly ash) }\end{array}$ \\
\hline $\mathrm{Si}$ & g/kg & $210-290$ & $95-190$ & $57-98$ & 120 \\
\hline $\mathrm{Al}$ & $\mathrm{g} / \mathrm{kg}$ & $47-72$ & $49-78$ & $17-46$ & $71-81$ \\
\hline $\mathrm{Fe}$ & g/kg & $27-150$ & $18-35$ & $3.6-18$ & $15-18$ \\
\hline $\mathrm{Ca}$ & g/kg & $65-97$ & $74-130$ & $170-290$ & $03-110$ \\
\hline $\mathbf{M g}$ & g/kg & $7.7-19$ & $11-19$ & $7.1-12$ & $18-23$ \\
\hline $\mathrm{K}$ & $\mathrm{g} / \mathrm{kg}$ & $9.2-22$ & $23-47$ & $27-40$ & $35-58$ \\
\hline $\mathrm{Na}$ & $\mathrm{g} / \mathrm{kg}$ & $22-41$ & $22-57$ & $12-19$ & $28-33$ \\
\hline $\mathrm{Ti}$ & g/kg & $3.2-7.2$ & $7.5-12$ & $1.5-5.1$ & $5.3-8.4$ \\
\hline$S$ & g/kg & $1.3-8$ & $11-32$ & $8-18$ & $11-26$ \\
\hline a & g/kg & $1.2-3.2$ & $45-101$ & $92-220$ & $48-71$ \\
\hline $\mathbf{P}$ & g/kg & $2.9-13$ & $4.8-9.6$ & $1.7-4.6$ & $6.0-7.4$ \\
\hline $\mathrm{Mn}$ & g/kg & $<0.7-1.7$ & $0.8-1.7$ & $0.3-0.7$ & $1.4-2.4$ \\
\hline $\mathrm{Ag}$ & $\mathrm{mg} / \mathrm{kg}$ & 4.1-14 & $31-95$ & $14-60$ & 53 \\
\hline As & $\mathrm{mg} / \mathrm{kg}$ & $19-80$ & $49-320$ & $40-260$ & $130-190$ \\
\hline $\mathrm{Ba}$ & $\mathrm{mg} / \mathrm{kg}$ & $900-2700$ & $920-1800$ & $310-1400$ & $330-1900$ \\
\hline $\mathrm{Be}$ & $\mathrm{mg} / \mathrm{kg}$ & nd & nd & $0.5-0.9$ & $1.5-1.9$ \\
\hline $\mathrm{Cd}$ & $\mathrm{mg} / \mathrm{kg}$ & $1.4-40$ & $250-450$ & $140-300$ & $220-270$ \\
\hline Co & $\mathrm{mg} / \mathrm{kg}$ & $<10-40$ & $29-69$ & 4-15 & $14-22$ \\
\hline $\mathrm{Cr}$ & $\mathrm{mg} / \mathrm{kg}$ & $230-600$ & $140-530$ & $150-570$ & $390-660$ \\
\hline $\mathrm{Cu}$ & $\mathrm{mg} / \mathrm{kg}$ & $900-4800$ & $860-1400$ & $450-1100$ & $1000-1400$ \\
\hline $\mathrm{Hg}$ & $\mathrm{mg} / \mathrm{kg}$ & $<0.01-3$ & $0.8-7$ & $0.3-44$ & $38-390$ \\
\hline Mo & $\mathrm{mg} / \mathrm{kg}$ & $2.5-40$ & $15-49$ & $9.3-20$ & $20-38$ \\
\hline $\mathrm{Ni}$ & $\mathrm{mg} / \mathrm{kg}$ & $60-190$ & $92-240$ & $20-63$ & $67-110$ \\
\hline $\mathrm{Pb}$ & $\mathrm{mg} / \mathrm{kg}$ & $1300-5400$ & $7400-19000$ & $4000-6500$ & $5900-8300$ \\
\hline $\mathrm{Se}$ & $\mathrm{mg} / \mathrm{kg}$ & $0.6-8$ & $6.1-31$ & $8.2-16$ & 12 \\
\hline $\mathrm{Sn}$ & $\mathrm{mg} / \mathrm{kg}$ & $<100-1300$ & $1400-1900$ & $620-780$ & 1000 \\
\hline $\mathrm{Sr}$ & $\mathrm{mg} / \mathrm{kg}$ & $170-350$ & $<80-250$ & $400-500$ & 200 \\
\hline $\mathrm{V}$ & $\mathrm{mg} / \mathrm{kg}$ & $36-90$ & $32-150$ & $26-62$ & 62 \\
\hline w & $\mathrm{mg} / \mathrm{kg}$ & $<20-50$ & nd & nd & nd \\
\hline $\mathrm{Zn}$ & $\mathrm{mg} / \mathrm{kg}$ & $1800-6200$ & $19000-41000$ & $12000-19000$ & $20000-23000$ \\
\hline PAH & $\mu g / k g$ & $0.23-2200$ & $30-110$ & $18-5600$ & nd \\
\hline $\mathrm{CB}$ & $\mu \mathrm{g} / \mathrm{kg}$ & $6.7-45$ & $50-890$ & 220 & nd \\
\hline $\mathrm{PCB}$ & $\mu g / k g$ & $<40$ & $<40$ & $<40$ & nd \\
\hline $\mathbf{C P}$ & $\mu g / k g$ & $16-34$ & $120-1800$ & 860 & nd \\
\hline PCDD & $\mu \mathrm{g} / \mathrm{kg}$ & $0.2-10$ & $115-140$ & $0.7-1000$ & 260 \\
\hline PCDF & $\mu g / k g$ & $0.44-4.5$ & $48-69$ & $1.4-370$ & 120 \\
\hline TCDD-eqv ${ }^{2}$ & $\mu \mathrm{g} / \mathrm{kg}$ & $0.02-0.22$ & $1.5-2.5$ & $0.8-2$ & 2.8 \\
\hline TOC & g/kg & $4.8-13$ & $4.9-17$ & $6-9$ & 7 \\
\hline LOI & $g / \mathrm{kg}$ & $5.9-50$ & $11-45$ & $28-49$ & 110 \\
\hline
\end{tabular}

'TCDD-toxicity equivalents determined according to Eadon's method.

$\begin{array}{ll}\text { Nd: } & \text { No data available. } \\ \text { PAH: } & \text { Polycyclic aromatic hydrocarbons. } \\ \text { CB: } & \text { Chlorobenzenes. } \\ \text { CP: } & \text { Chlorophenols. } \\ \text { PCDD: } & \text { Polychlorinated dibenzo-p-dioxins } \\ \text { PCDF: } & \text { Polychlorinated dibenzofurans. } \\ \text { TOC: } & \text { Total organic carbon. } \\ \text { LOI: } & \text { Loss on ignition }\left(550^{\circ} \mathrm{C}\right) .\end{array}$


From Table 1 it is seen that the major elements (present in concentrations exceeding $10 \mathrm{~g} / \mathrm{kg}$ ) are nearly the same for all residues shown: $\mathrm{Si}, \mathrm{Al}, \mathrm{Fe}, \mathrm{Ca}, \mathrm{Mg}$, $\mathrm{Na}, \mathrm{K}, \mathrm{S}$ (except for bottom ash), $\mathrm{Cl}$ (not for bottom ash), $\mathrm{Zn}$ (not for bottom ash) and $\mathrm{Pb}$ (only for fly ash). Many of these elements are present as oxides. The concentration of the various trace elements varies between the two types of residues; some e.g. $\mathrm{Ba}$ and $\mathrm{Cr}$ are present at the same concentration level in all residues, some notably $\mathrm{Cu}$ are usually enriched in the bottom ash, whereas several trace elements, particularly the more volatile elements (e.g. $\mathrm{Cd}, \mathrm{Hg}, \mathrm{As}, \mathrm{Pb}$ and $\mathrm{Zn}$ ) are enriched in the fly ash and the acid gas scrubbing residues.

\section{LEACHING BEHAVIOUR OF MSWI RESIDUES}

The potential leaching and release of components which may adversely affect the environment are obviously important properties in relation to disposal and utilisation of the residues and management of the leachate. Evaluation of the environmental impact related to the leaching of constituents from MSWI residues must ideally be based on information regarding both the short term (months to years) and the long term (several hundreds of years) leaching behaviour of constituents from the residues. Some data on the short term behaviour of most MSWI residues are available, and the evaluation of the short term behaviour may to a large extent be based on the results of laboratory and short term field experiments. Due to the scarcity of long term observations, the long term behaviour of the residues is much less understood. Evaluation of the long term behaviour requires use of different methodologies, e.g. simulation of long term conditions, extrapolation of the results of fundamental laboratory leaching testing, hydrogeochemical modelling and field studies.

Table 2 presents an overview of the maximum levels of concentrations of inorganic salts, trace elements and non-volatile organic carbon (NVOC) observed in initial leachate from the major types of MSWI residues. The concentration levels represent data from a number of laboratory leaching tests (mostly column tests) and a few field investigations (summarised in Hjelmar, 1996). 
Tiable 2. Maximum concentration levels of contaminants in leachates from MSWI residues. Compiled in Hjelmar (1996).

\begin{tabular}{|c|c|c|c|c|}
\hline $\begin{array}{l}\text { Typical maximum } \\
\text { levels of concentra- } \\
\text { tion in leachate }\end{array}$ & Unit & MSWI bottom ash & $\begin{array}{l}\text { MSWI fly ash and resi- } \\
\text { dues from dry and sem- } \\
\text { dry APC processes }\end{array}$ & $\begin{array}{c}\text { Mixture of } \\
\text { MSWI fly ash } \\
\text { and sludge from } \\
\text { wet scrubbing } \\
\text { process }\end{array}$ \\
\hline$>100$ & $g / 1$ & & $\mathrm{Cl} ; \mathrm{Ca}$ & \\
\hline $10-100$ & $g / 1$ & & $\mathrm{Na}, \mathrm{K}, \mathrm{Pb}$ & $\mathrm{Cl}^{\prime}, \mathrm{Na}, \mathrm{K}$ \\
\hline $1-10$ & $g / 1$ & $\mathrm{SO}_{4}{ }^{2-}, \mathrm{Cl}^{-}, \mathrm{Na}, \mathrm{K}, \mathrm{Ca}$ & $\mathrm{Zn}$ & $\mathrm{SO}_{4}{ }^{2 \cdot}, \mathrm{Ca}$ \\
\hline $100-1000$ & $\mathrm{mg} / \mathrm{l}$ & NVOC, $\mathrm{NH}_{4}-\mathrm{N}$ & $\mathrm{NVOC}, \mathrm{SO}_{4}{ }^{2 \cdot}$ & \\
\hline $10-100$ & $\mathrm{mg} / \mathrm{l}$ & & & \\
\hline $1-10$ & $\mathrm{mg} / \mathrm{l}$ & $\mathrm{Cu}, \mathrm{Mo}, \mathrm{Pb}$ & $\mathrm{Cu}, \mathrm{Cd}, \mathrm{Cr}, \mathrm{Mo}$ & NVOC, Mo \\
\hline $100-1000$ & $\mu \mathrm{g} / \mathrm{l}$ & $\mathrm{Mn}, \mathrm{Zn}$ & As & \\
\hline $10-100$ & $\mu \mathrm{g} / \mathrm{l}$ & $\mathrm{As}, \mathrm{Cd}, \mathrm{Ni}, \mathrm{Se}$ & & As, Cr, Zn \\
\hline $1-10$ & $\mu \mathrm{g} / \mathrm{l}$ & $\mathrm{Cr}, \mathrm{Hg}, \mathrm{Sn}$ & & $\mathrm{Pb}$ \\
\hline$<1$ & $\mu \mathrm{g} / \mathrm{l}$ & & $\mathrm{Hg}$ & $\mathrm{Cd}, \mathrm{Cu}, \mathrm{Hg}$ \\
\hline
\end{tabular}

For most parameters, the maximum concentrations occur in the initial leachate, and most of the concentrations shown in Table 2 have been observed in fractions of leachate collected at or below $\mathrm{L} / \mathrm{S}=0.5 \mathrm{l} / \mathrm{kg}$. L/S is the liquid/solid or leachate/waste ratio. For a particular utilised or deposited mass of residue, $S$ will be constant and $\mathrm{L}$ will increase as the leachate is formed. An L/S scale may therefore be transformed to a time scale if the rate of percolation or flow through the site is known.

The various MSWI residues differ substantially from each other in terms of water solubility. Only a small fraction, often less than $5 \%$, of the total mass of the bottom ash is soluble is water whereas 20 to $25 \%$ of the total mass of the fly ash and 30 to $40 \%$ of the total mass of the dry/semidry acid gas scrubbing residues consist of salts which are readily soluble in water.

\section{EXAMPLE: UTILISATION OF MSWI BOTTOM ASH AS A SUB BASE AT A PARKING LOT}

In 1974, approximately 4,000 tonnes of MSWI bottom ash (screened and treated magnetically to remove ferrous material) were used as sub-base under a parking lot in Ballerup near Copenhagen. A $40 \mathrm{~cm}$ layer of bottom ash was placed on top of a $100 \mathrm{~cm}$ thick layer of gravel (drainage layer). The site was paved with flagstones embedded in $14 \mathrm{~cm}$ of gravel which was placed on top of the bottom ash, see figure 2. The entire site which covers an area of 9,300 me is drained at the bottom of the drainage layer. A 200 me plastic liner was placed between the ash and drainage layer, and provisions were made to enable collection of drainage 
water, leachate (running off the top of the liner) and surface run-off. Samples of each have been collected annually or biannually over periods of a few days (during rain events) since 1975. The rate of infiltration through the bottom ash layer is estimated at $140 \mathrm{~mm} / \mathrm{year}$.

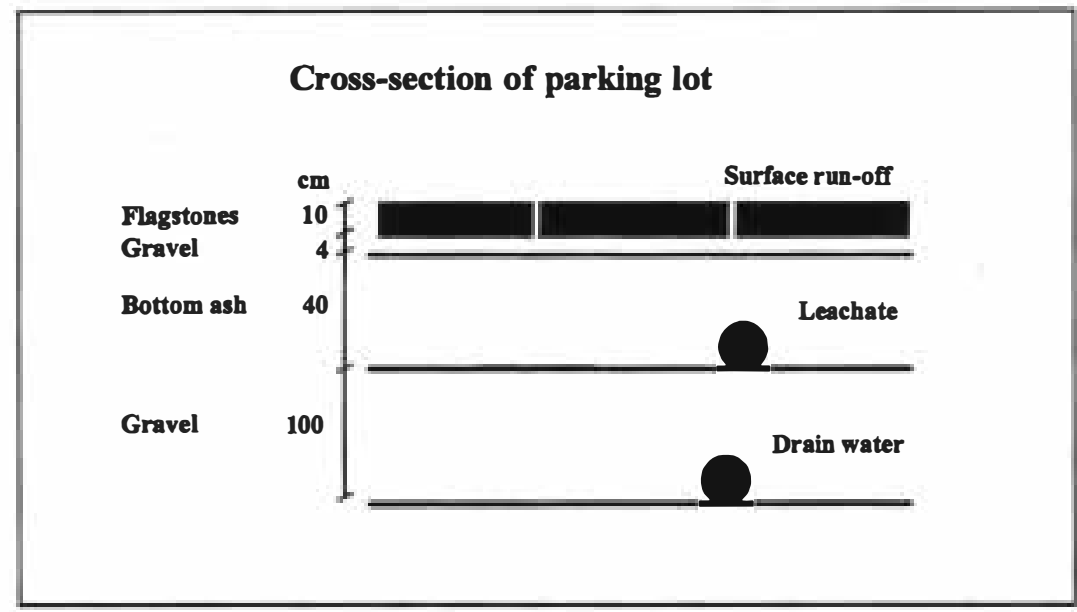

Fig: 2: Cross-section of parking lot in Ballerup with MSWI bottom ash sub-base.

Ranges of the composition of the surface run-off, the leachate and the drainage water (leachate which has passed $100 \mathrm{~cm}$ of drainage gravel) collected from 1975 to 1995 are presented in Table 3.

Table 3. Ranges of composition of surface run-off, leachate and drainage water collected during 1975-1995 at a parking lot under which MSWI bottom ash has been used as subbase.

\begin{tabular}{|c|c|c|c|c|}
\hline Parameter & Unit & Surface run-off & Leachate & Drainage water \\
\hline $\mathrm{pH}$ & & $7.2-8.1$ & $7.1-8.6$ & $6.5-8.3$ \\
\hline $\mathrm{Cl}^{-}$ & $\mathrm{mg} / \mathrm{l}$ & $4-41 \quad(520)$ & $140-2200$ & $230-910$ \\
\hline Total-N & $\mathrm{mg} / \mathrm{l}$ & $0.7-6.0 \quad(1100)$ & $4.7-200$ & $2.0-92$ \\
\hline $\mathrm{Cd}$ & $\mathrm{mg} / 1$ & $<0.0001-0.0006$ & $<0.00005-0.0005$ & $<0.0001-0.001$ \\
\hline $\mathrm{Cr}$ & $\mathrm{mg} / \mathrm{l}$ & $<0.001$ & $<0.001$ & $<0.001-0.002$ \\
\hline $\mathrm{Cu}$ & $\mathrm{mg} / 1$ & $0.002-0.05$ & $<0.001-0.002$ & $0.002-0.014$ \\
\hline $\mathrm{Pb}$ & $\mathrm{mg} / \mathrm{l}$ & $<0.001-0.079$ & $<0.001-0.014$ & $<0.001-0.010$ \\
\hline $\mathrm{Zn}$ & $\mathrm{mg} / \mathrm{l}$ & $<0.01-0.12$ & $<0.01-0.19$ & $<0.01-0.09$ \\
\hline
\end{tabular}

( ): extreme values 
The total amount of leachate generated is difficult to estimate but corresponds to approximately $0.31 / \mathrm{kg}$ in 1975 and approximately $\mathrm{L} / \mathrm{S}=4 \mathrm{l} / \mathrm{kg}$ in 1995 . The leachate is primarily characterised by its inorganic salt content and its relatively low concentrations of heavy metals. The highest concentrations of lead and cadmium were observed in the surface run-off from the parking lot. The relatively high concentrations of chloride and total nitrogen found in one of the surface run-off water samples were probably related to the use of sodium chloride and urea as deicing agents during the winter.

In 1995 samples of the 21 year old bottom ash were obtained and used for solid phase characterisation and leaching behaviour. Table 4 shows the results of the characterisation of the old bottom ash compared with fresh botttom ash sampled in 1993 and 1995 from the same MSW incinerator.

Table 4. Total composition of the MSWI bottom ash sampled under the parking lot and fresh bottom ash from 1993 and 1995.

\begin{tabular}{|c|c|c|c|c|c|}
\hline Parameter & Unit & \multicolumn{4}{|c|}{ Bottom Ash } \\
\hline & & OldA & Old B & Fresh 1993 & Fresh 1995 \\
\hline $\mathrm{pH}$ & - & 9.3 & 9.2 & - & 10.4 \\
Alkalinity & $\mathrm{mmol} / \mathrm{g}$ & 2.2 & 2.2 & - & 3.1 \\
Loss on ignition & $\mathrm{g} / \mathrm{kg}$ & 47 & 43 & 33 & 24 \\
$\mathrm{NVOC}$ & $\mathrm{g} / \mathrm{kg}$ & 19 & 20 & - & 17 \\
$\mathrm{Si}$ & $\mathrm{g} / \mathrm{kg}$ & 240 & 240 & 180 & 230 \\
$\mathrm{Al}$ & $\mathrm{g} / \mathrm{kg}$ & 45 & 46 & 59 & 65 \\
$\mathrm{Fe}$ & $\mathrm{g} / \mathrm{kg}$ & 78 & 83 & 120 & 71 \\
$\mathrm{Ca}$ & $\mathrm{g} / \mathrm{kg}$ & 64 & 65 & 110 & 93 \\
$\mathrm{Mg}$ & $\mathrm{g} / \mathrm{kg}$ & 8.0 & 8.1 & 8.5 & 11 \\
$\mathrm{Mn}$ & $\mathrm{g} / \mathrm{kg}$ & 1.7 & 2.0 & 1.7 & 1.3 \\
$\mathrm{Ti}$ & $\mathrm{g} / \mathrm{kg}$ & 2.9 & 3.0 & 7.2 & 7.9 \\
$\mathrm{P}$ & $\mathrm{g} / \mathrm{kg}$ & 4.3 & 4.2 & 5.6 & 4.4 \\
$\mathrm{~K}$ & $\mathrm{~g} / \mathrm{kg}$ & 10 & 10 & 11 & 10 \\
$\mathrm{Na}$ & $\mathrm{g} / \mathrm{kg}$ & 42 & 41 & 21 & 33 \\
$\mathrm{~S}$ & $\mathrm{~g} / \mathrm{kg}$ & 1.1 & 1.0 & 5.1 & 3.5 \\
$\mathrm{Cl}$ & $\mathrm{g} / \mathrm{kg}$ & 0.5 & 0.5 & 3.3 & 3.3 \\
$\mathrm{As}$ & $\mathrm{mg} / \mathrm{kg}$ & 41 & 36 & 44 & 27 \\
$\mathrm{Ba}$ & $\mathrm{mg} / \mathrm{kg}$ & 1400 & 1100 & 1050 & 1500 \\
$\mathrm{Cd}$ & $\mathrm{mg} / \mathrm{kg}$ & 6.9 & 6.4 & 11 & 1.4 \\
$\mathrm{Cr}$ & $\mathrm{mg} / \mathrm{kg}$ & 210 & 230 & - & 320 \\
$\mathrm{Ca}$ & $\mathrm{mg} / \mathrm{kg}$ & 2200 & 2400 & 7800 & 15000 \\
$\mathrm{Hg}$ & $\mathrm{mg} / \mathrm{kg}$ & 0.29 & 0.14 & - & $<0.2$ \\
$\mathrm{Ni}$ & $\mathrm{mg} / \mathrm{kg}$ & 130 & 290 & 210 & 320 \\
$\mathrm{~Pb}$ & $\mathrm{mg} / \mathrm{kg}$ & 2300 & 2300 & 2100 & 2400 \\
$\mathrm{Zn}$ & $\mathrm{mg} / \mathrm{kg}$ & 4000 & 3900 & - & 4500 \\
\hline
\end{tabular}


The data presented in Table 4 show that the $\mathrm{pH}$ of the aged ash is lower than the $\mathrm{pH}$ of the fresh ash sampled in 1993 and 1995. The lower $\mathrm{pH}$ in the aged bottom ash is probably caused partly by carbonisation (uptake of carbon dioxide) and partly by leaching of alkalinity with percolating water. This was further confirmed by measurements of $\mathrm{pH}$ as a function of depth in the bottom ash. $\mathrm{pH}$ increased from approximately 8.3 at the top to a $\mathrm{pH}$ of 9.3 to 10 at the bottom of the layer.

For an evaluation of the future leaching behaviour of the 21 year old bottom ash, samples of this ash were subjected to different leaching tests, including column leaching tests $(\mathrm{L} / \mathrm{S}=0.1,0.2,0.5,1.0)$, availability tests $(2 \times \mathrm{L} / \mathrm{S}=100 \mathrm{l} / \mathrm{kg}, \mathrm{pH}=$ 7 and $\mathrm{pHe}=4)$, serial batch leaching tests for granular waste $(\mathrm{L} / \mathrm{S}=2,10,50)$ and $\mathrm{pH}$-static leaching tests at $\mathrm{pHe}=2,4,6,7,8,9,10,11(\mathrm{~L} / \mathrm{S}=5)$. In Figure 3 examples of the leaching behaviour of chloride and lead are shown in terms of results from the availability test and the serial batch leaching test

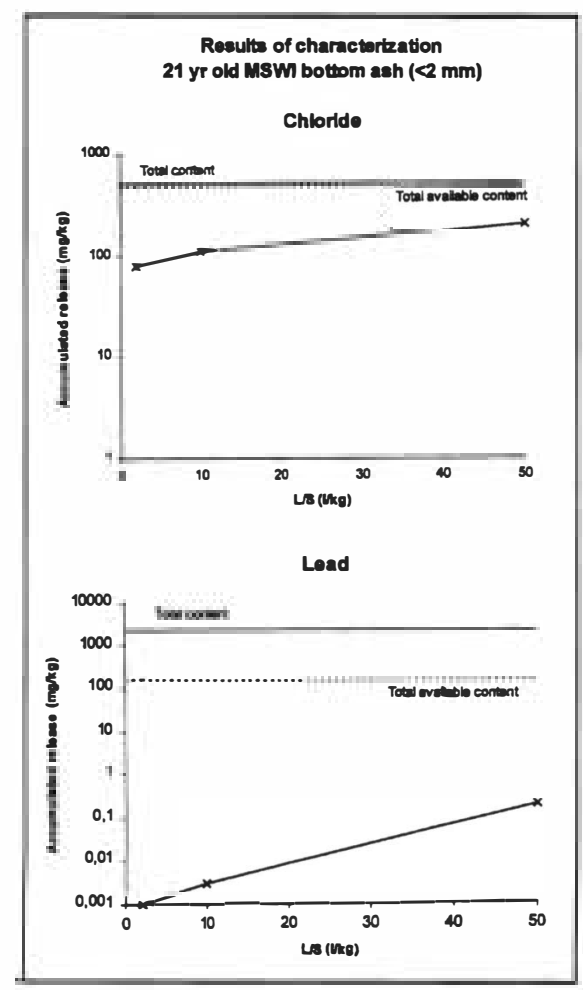

Fig. 3: Accumulated release of lead and chloride from 21 year old MSWI bottom ash shown as function of the $L S$-ratio. 
The results for chloride shown in Figure 3 show that the amount of chloride characterised as available for leaching approximates the total concentration of chloride found in the ash, and the accumulated release of chloride increases as a function of $\mathrm{L} / \mathrm{S}$ and has at $\mathrm{L} / \mathrm{S}=50 \mathrm{l} / \mathrm{kg}$ reached approximately $40 \%$ of the total amount of chloride available for leaching. As expected, this behaviour is different from the one observed for the trace elements, here exemplified by lead. A large fraction of the lead found in the ash is not available for leaching as shown by the results of the availability test and the serial batch leaching test. This type of information contributes to a better understanding of the leaching behaviour of these two elements and exemplifies that salts like chloride are relatively easily leached from bottom ash, whereas many trace elements are strongly bound within the solid matrix and only to a limited extent available for leaching.

Further information of the leaching behaviour can be obtained through the performance of $\mathrm{pH}$-static leaching test as shown in Figure 4.

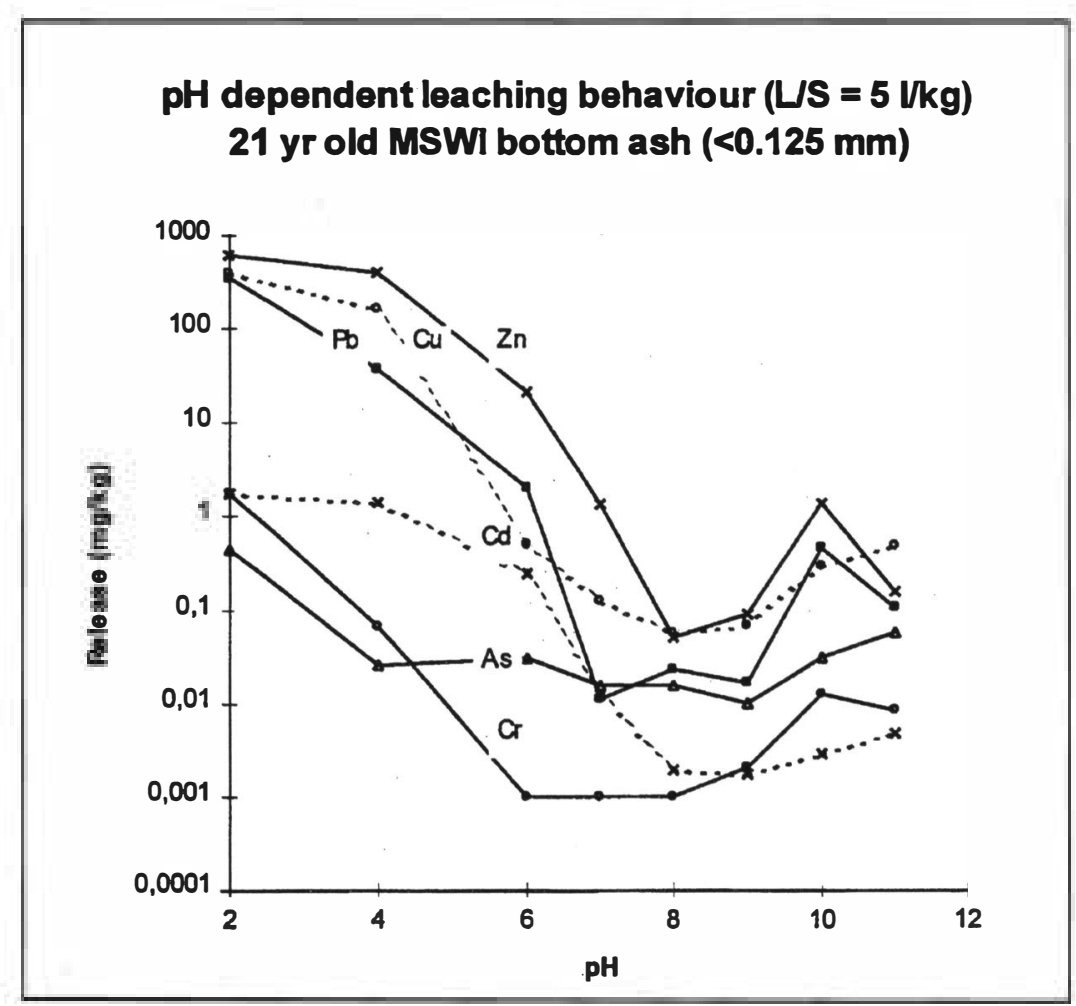

Fig. 4. pH dependent leaching behaviour of a 21 year old MSWI bottom ash. 
$\mathrm{pH}$ is probably the single most important factor controlling the leaching behaviour of trace elements from incineration residues. The information from this type of testing illustrates the $\mathrm{pH}$-dependent leaching behaviour of the elements found in the slag. The different form of the leaching curves representing the elements reflect the solubility of the different minerals present in the slag.

\section{CONCLUSION AND SUMMARY}

This paper presents a number of data on the composition and leachability of MSWI residues. Based on these data it can be concluded that:

The bottom ash contains high concentration of several salts and trace elements.

The leachate from the bottom ash contains high initial salt, ammonia, NVOC concentrations and relatively low concentrations of trace elements.

Results of field and laboratory leaching tests may provide good basis for evaluation of leaching behaviour of contaminant from combustion residues. However, only a few long term studies of actual utilisation of MSWI bottom ash are available and there is a need for further long term field observations and laboratory experiments.

\section{REFERENCES:}

IAWG (1997) The International Ash Working Group: Chandler, A.J.; Eighmy, T.T.; Hartlén, J.; Hjelmar, O.; Kosson, D.S.; Sawell, S.E.; van der Sloot, H.A. \& J. Vehlow: Municipal solid waste incineration residues. Studies in Environmental Science 67. Elsevier, The Netherlands.

Hjelmar, O. (1996): Disposal strategies for municipal solid waste incineration residues. Journal of Hazardous Materials 47: 345-368.

DOI: https://doi.org/10.1016/0304-3894(95)00111-5 